\title{
PIOUS PHYSIC FOR THE POOR: THE LOST DURHAM COUNTY MEDICAL SCHEME OF 1655
}

by

\section{DAVID HARLEY *}

The provision of some sort of medical care for the poor was widely recognized in late medieval and early modern Europe as a religious duty and a civic necessity. The choice of methods depended upon a variety of local factors, such as religious politics, the political situation, the scope of bureaucratic intervention, and the development of the medical professions. The political will to provide new services often arose from the crisis generated by an outbreak of plague, but it could also be part of a general extension of poor relief motivated by considerations of public order or part of an evangelical campaign in response to religious divisions. Although more usually associated with the city states of Italy, the appointment of civic doctors was not unknown in Protestant Europe, as the well-known examples of Pieter van Foreest in Delft and Johannes Wier in Arnhem demonstrate. ${ }^{1}$ Some English towns did appoint town physicians, at least intermittently, but only such major cities as Norwich appear to have made serious attempts to cope with the problem of the sick poor before $1640 .^{2}$

The Durham medical scheme of 1655 appears to have been England's first comprehensive plan for medical poor relief on a county basis. It is mentioned in the Hartlib Papers under the heading. 'Physicall Charity, Durham College, Septemb.4.1658' ${ }^{3}$ One of Samuel Hartlib's correspondents at the newly established university in Durham Castle wrote to him on that date, promising to send news of the

* David N. Harley, 17 Arlington Drive, Old Marston, Oxford OX3 0SH

A version of this essay was read during a conference organized by the Hartlib Papers Project at Sheffield University, 6-8 July 1992. I am grateful to those who discussed it there.

'The town and state physician in Europe from the Middle Ages to the Enlightenment, ed. A. W. Russell, Wolfenbütteler Forschungen 17, 1981; K. Park, Doctors and medicine in early Renaissance Florence, Princeton University Press, 1985, pp. 87-99; C. M. Cipolla, Public health and the medical profession in the Renaissance, Cambridge University Press, 1976; M. J. van Lieburg, "Over de stadsmedicus in de Noord-Nederlandse steden van de 16e eeuw', in Pieter van Foreest: een Hollands medicus in de zestiende eeuw, ed. H. L. Houtzager, Amsterdam, Rodopi, 1989, pp. 41-72.

${ }^{2}$ M. Pelling, 'Healing the sick poor: social policy and disability in Norwich, 1550-1640', Med. Hist., 1985, 29: 115-37. Scattered records of appointments exist for Barnstaple, Chester, Denbigh and King's Lynn, among others. Only Newcastle is known to have regularly filled the post of town's physician: see note 8 below.

${ }^{3}$ Sheffield University Library: Hartlib MS 53/12/1-2. I am grateful to the Library for providing me with a photocopy of the manuscript. Contemporaries usually spelled Tonstall's name phonetically, i.e. Tunstall. His own usage has been adopted in this essay. The correspondent's name does not appear and there is no other reference to the scheme in the Hartlib papers. Presumably the College did not take up the proposal. 


\section{Pious physic for the poor}

ideas behind the scheme proposed by $\mathrm{Dr}$ Tonstall and details of why it was not proceeding, and to send a copy of the order of the Grand Jury concerning it. Later that month, Hartlib received the promised transcript of the order of 25 April 1655. The Grand Jury of County Durham had considered the proposal of Dr George Tonstall of the City of Durham to "furnish the poore inhabitants of this County Gratis with aduice in all Cases wherin Physick and Chirurgerie is necessary \& also with Physick and Medicaments." The plan was to be supported by subscriptions, which would go towards paying an apothecary and a surgeon and buying medicines. The Grand Jury approved of this plan and wished it to be recommended to the clergy and parish officers of the county. According to a letter sent to Hartlib's correspondent by Tonstall in January 1657, the magistrates had refused the request of the Grand Jury to promote the scheme. Tonstall asked God to forgive them for having on their hands the blood of the poor who died of curable diseases for want of help. He piously hoped that the Durham College would consider taking up the scheme.

The existence of this pioneering proposal was noticed by Charles Webster in The great instauration, where it was cited as an example of the kind of innovation advocated by the Hartlib circle. ${ }^{4}$ In the absence of any surviving Quarter Sessions papers for County Durham during the Interregnum, it appeared that the scheme's precise content would have to remain a mystery. The project was clearly of a broadly Hartlibian kind, religiously motivated, and intended to be supported by private donations rather than the public purse. This tantalizing glimpse was apparently all that could ever be known of the plan.

It now transpires that there survives a single copy of the pamphlet put out by George Tonstall after the idea had been rejected by the magistrates. The title page is missing, but all the text is intact. ${ }^{5}$ It is therefore possible to consider in some detail the content and the motivation of the participants.

Three physicians seem to have been involved in proposing the scheme. The most active was George Tonstall, the pamphlet's author. He was the grandson of a leading clergyman and the son of Tobias Tonstall, a gentleman of Cleasby in Yorkshire, a village close to Darlington, who had been educated at Cambridge and Gray's Inn. George Tonstall matriculated at Queen's College, Oxford, at the age of 17 in 1634 and took his MA as a member of Magdalen Hall in 1640. According to Antony Wood, he had intended to become a clergyman but turned to practising medicine on the outbreak of the Civil War. He obtained his Bachelor of Medicine degree in April 1647.6 During the $1650 \mathrm{~s}$, he practised in Durham where he rapidly acquired a reputation for diligence and piety. Joseph Lister, a steward near Hartlepool, was dissatisfied with the physician who had been attending him,

So having paid him off, I sent to a physician at Durham, twelve miles off. He was a good man, I believe; and they said, a young convert: his name was Dr. Tunstale. He

\footnotetext{
${ }^{4}$ C. Webster, The great instauration, London, Duckworth, 1975, pp. 238, 300.

${ }^{5}$ Bodleian Library: Antiq.e.E.42 (7). T1888A in the revised Wing Short title catalogue.

${ }^{6} \mathrm{R}$. Surtees, The history and antiquities of the County Palatine of Durham, 3 vols, London, 1823, vol. 3, p. 272; Antony à Wood, Athenae Oxonienses, ed. P. Bliss, 4 vols, London, 1817, vol. 3, col. 985.
} 


\title{
David Harley
}

sent me something by my messenger, and said, he would come on the morrow to see me, which he did. He first let me blood, and gave me what he thought proper; and God so blessed his prescriptions, that I did soon recover. ${ }^{7}$

Since Tonstall was not a young man and his family were staunch Protestants, it is clear that the phrase, "a young convert", means that he had recently joined the ranks of the godly. From his writings and friendships, he would appear to have been a Presbyterian.

After the Restoration, he moved to Newcastle before the new Bishop of Durham was installed and became town physician there from 1660 to 1664 at the usual salary of $£ 40$ per annum. Newcastle had been without a town physician for six years, since the death of the quarrelsome Samuel Rand, MD, FCP. ${ }^{8}$ Tonstall was probably encouraged to move there by Richard Gilpin, who had been one of the Visitors to Durham College when it was established in 1657 . He presumably forfeited this post as a result of his nonconformity. In the 1660s, he was a member of Gilpin's illegal conventicle at the Barber-Surgeon's Hall in Newcastle where Gilpin preached the series of sermons that was to form the basis of his Leyden MD thesis of 1676, 'de Hysterica passione', and the treatise to which he owed his fame, the Daemonologia sacra of $1677 .{ }^{9}$ According to Gilpin's patron, Alderman Ambrose Barnes,

\begin{abstract}
There was a long intimacy between him and that pious learned physition Dr. Tonstal, a gentleman of an ancient house, and of great strictness in religion, if his scruples, by a tincture of melancholy, had not in some humours carried him into excess. From a rooted opinion, how next to impossible it is, for a rich man to be saved, he omitted some very warrantable advantages, to the prejudice of his family. To him was Dr. Gilpin greatly beholden for his improvement in physic, after his coming to Newcastle.
\end{abstract}

Barnes also relates how Tonstall "had, with great pains and expence, laboured in the fire and study of the hermetic secret, and a comical thing it was to hear him harangue upon his own experiments." 10

In 1670, Tonstall entered the famous dispute between Wittie and Simpson about the Scarborough spa, in a foolhardy attempt to "walk uniformly betwixt Dr. Witty's Library and Mr. Simpson's Laboratory," citing Hippocrates and van Helmont as his guiding lights. For his pains, he was savaged by Wittie, so he replied in kind in a second book which was highly critical of Wittie's use of evidence and his medical practice. Although some invalids, such as Bishop Wilkins of Chester, were disturbed by Tonstall's allegations, the Yorkshire medical establishment rallied round Wittie. Nathaniel Johnston wrote to Martin Lister, "I have seen Dr Tonstalls booke. If he write long in this manner he will write himself out of repute. It will not be worth Dr

${ }^{7}$ An historical relation of the life of Mr. Joseph Lister, Bradford, 1821, pp. 37-8.

$8 \mathrm{~J}$. Brand, The history and antiquities of the town and county of Newcastle upon Tyne, 2 vols, London, 1789, vol. 2, p. 363; 'Extracts from the municipal accounts of Newcastle-upon-Tyne', in Newcastle Tracts, 3 vols, Newcastle, 1848, vol. 3, pp. 47, 50, 59.

${ }^{9}$ Memoirs of the life of Mr. Ambrose Barnes, Surtees Society, 1867, 50: 374, 405-8; R. Gilpin, Disputatio medica inauguralis: de hysterica passione, Leyden, 1676; idem, Daemonologia sacra: or, a Treatise of Satans temptations, London, 1677; D. N. Harley, 'Mental illness, magical medicine and the devil in northern England, 1650-1700', in The medical revolution of the seventeenth century, ed. R. French and A. Wear, Cambridge University Press, 1989, pp. 123-4.

${ }^{10}$ Life of Barnes, note 9 above, pp. 153-4. 
Wittys paines to give an answer where neither new tryalls or arguments are brought." 11 The aloof Galenism of the conforming ex-Presbyterian Wittie was more congenial to his colleagues than the irate Helmontianism of his nonconformist rival. Throughout his career, Tonstall appears to have practised a blend of moderate Helmontian physic and pious Calvinist providentialism. Thus in 1677 , towards the end of his life, he said of Ralph Thoresby's brother that "greif and sadness ... did not break his heart because a Christian, yet it dried his liver." 12 Tonstall's will has not been found, but it seems likely that the sale of his books in London was necessitated by the need to provide a modest inheritance for his six children.

Tonstall was joined in the scheme by two other physicians, William Tonstall and Edward Wilson. The former was his younger brother, who had followed him to Oxford but left without taking a degree. He was probably working in Durham as George Tonstall's pupil. The involvement of Dr Edward Wilson, nominated as Tonstall's successor in the scheme, is more striking because he was a Roman Catholic, repeatedly presented at diocesan visitations and convicted for recusancy during the reign of Charles II. $^{13} \mathrm{He}$ presumably obtained an MD at a Continental university, since Tonstall refers to him as a doctor, something he does not say of himself, but it is not known which university. Wilson's involvement indicates a desire on Tonstall's part to include the Catholic poor as recipients of the charity and to draw the Catholic gentry into supporting the scheme. Hence the remarkable concession on page 5 of the pamphlet, that sick recusants need not be attended by a Protestant minister.

Why would a Calvinist like Tonstall make such efforts to obtain support from Catholics? Some ministers, for example Richard Vines, had long argued in favour of a distinction between tolerating those peaceable heretics, Jews, Muslims and papists who did not evangelize, and prosecuting those who did. This message appears to have been attractive to the chemical physicians, who had no difficulty respecting the Catholic chemist Sir Kenelm Digby. In thus going beyond the Protestant eirenicism of Hartlib towards a genuine religious pluralism, they anticipated the Royal Society. An example of this approach can be found in the works of John French, an Oxford educated Paracelsian who was physician to the Savoy Hospital and an associate of the Hartlib circle. Whereas Edmund Deane had derided St Mungo's Well as "an ineffectual superstitious relique of Popery", French argued it was decidedly useful. In his 1652 book, The York-shire Spaw, he wrote,

Now for the conclusion of all, let not any one judge me to be a Catholick by this approbation of this Sainted Well, for I am none, and as none my self, so neither do I

\footnotetext{
${ }^{\prime \prime}$ R. F. Jones, Ancients and moderns, rev. ed., St Louis, Washington University Press, 1961, pp. 262-4; N. G. Coley, "Cures without Care". "Chymical physicians" and mineral waters in seventeenth-century English medicine', Med. Hist., 1979, 23: 191-214; D. N. Harley, 'Religious and professional interests in northern spa literature, 1625-1775', Bull. Soc. Soc. Hist. Med., 1984, 35: 14-16; G. Tonstall, Scarborough Spaw spagyrically anatomized, London, 1670, sig. A3v; idem, A New-Years-Gift for Doctor Witty, London, 1672; Bodleian Library: MS Lister 3, f. 193; MS Lister 35, f. 17.

12 British Library: MS Stowe 745, ff. 143-4.

${ }^{13}$ Durham University, Dept. of Palaeography: DDR II/3, f.114r; W. V. Smith, 'Recusant doctors in Northumberland and Durham, 1650-1790', Northern Catholic History, 1986, 23: 15-26. I am grateful to Margaret Pelling for providing me with a copy of this article.
} 


\section{David Harley}

hate those that are, or those of any other heterodox judgement whatsoever. Their living according to their own light, and within the bounds of civility, is a sufficient ground, for me to exercise good will, and love to them. ${ }^{14}$

Whereas earlier northern Protestant medical authors had seen the struggle against Catholicism as central to their work, Tonstall participates in the attempt to incorporate Catholics in the institutions of civil society as part of the restoration of order after the Civil War. Involving Dr Wilson in the poor relief scheme was not just intended to increase the number of potential subscribers.

Wilson remained a close colleague of Tonstall after the latter's removal to Newcastle. In 1670, they collaborated to produce a diagnosis of the wife of Archdeacon Dennis Grenville, who was endeavouring to have his wife declared insane as part of his struggle against his father-in-law, Bishop Cosin. Grenville took their report, along with the diagnoses of physicians in York and Oxford, including Robert Wittie, to London, but the fashionable physicians who were consulted there declared her to be suffering from nothing more serious than fits of the mother. They had probably been subjected to pressure by the Bishop, who triumphantly recorded their comment, "that the Durham certificate comes from men that are unworthy to practise physick, and that it smells more of ignorance and malice then of any reason or knowledge." Since all six of the provincial physicians consulted by Grenville agreed on the seriousness of his wife's condition and the need for drastic therapy, it seems likely that Wilson and Tonstall were being made scapegoats. ${ }^{15}$

In 1675, Wilson published his own contribution to northern spa literature, Spadacrene Dunelmensis, which he dedicated to John Sudbury, the Dean of Durham. The main polemical thrust of this book is an attack on radical chemistry. Wilson quotes extensively from The chymical Galenist, George Castle's assault on Marchamont Nedham, refers to French's book with respect, and supports Wittie against Simpson in the Scarborough spa dispute. ${ }^{16}$ Wilson was buried at St Oswald's, Durham, on 2 June 1680. Like many Restoration Catholics, he left no indication of his recusancy in his modest will. ${ }^{17}$

Having established the identity of the main participants in the proposal, it is possible to assess the main features of the text. The most prominent characteristic of Tonstall's appeal for support is his consistent reference to God's providence. He begins by mentioning "that Talent which God had given me" and talking of how "Providence did require I should put forward the motion for supply of the Poore"

\footnotetext{
${ }^{14} \mathrm{R}$. Vines, The authors, nature, and danger of haeresie, London, 1647, p.66; P. Elmer, 'Medicine, religion and the puritan revolution', in Medical revolution, note 9 above, pp. 10-45; M. Hunter, Establishing the new science, Woodbridge, Boydell, 1989, pp. 45-71; J. French, The York-shire spaw, or a treatise of four famous medicinal wells, London, 1652, pp. 1, 123.

${ }^{15}$ Bodleian Library: MS Rawl.D.851, ff. 109-11, printed in Remains of Denis Granville DD, Surtees Society, 1865, 47: pp. 7-10; The correspondence of John Cosin DD, part 2, Surtees Society, 1872, 55: pp. 244-5.

${ }^{16}$ E. W[ilson], Spadacrene Dunelmensis, London, 1675, sig.B5, pp. 54-6, 77. This work has sometimes been mistakenly attributed to a London physician.

${ }^{17}$ Durham Record Office: EP/Du SO 119; Durham University, Dept. of Palaeography: PROB 1680, T348. Local records have not shed light on the identity of Thomas Cooper, the surgeon named in the pamphlet. Presumably Tonstall had not yet reached an agreement with a chemist and an apothecary.
} 
(p.1), allusions to the Calvinist doctrine of vocation, which also underpins his later reference to the magistrates as "the Physitians deputed of God for reliefe of the poor" (p.5). Anticipating criticism on the grounds of his inability to carry out the task, Tonstall points out that God "delights to make his power known by effecting great works with most despicable and improbable Agents" (p.2). He therefore resolves to prosecute the scheme as far as he has God's assistance and blessing, if it pleases God to allow him to live long enough.

Tonstall's fourth reason in favour of the scheme is particularly worthy of note:

The Glory of God. We say, take away the Cause, and the Effect ceaseth; this is an undeniable Principle, yet ordinarily it is contradicted in the Physitians and Patients practice: For the Cause, Principall, Antecedant, Concomitant and sine qua non, is Sinne, and that in every Disease, this therefore in right Method should be removed, but it is the last thought upon. How would God blesse the proceedings of the Phisitian, and Sanctifie the sickenesse of the Patient, if that order were made, That none... should expect a Physitians assistance, before the Minister have Visited him, except the sicke party be a Recusant? (pp.4-5.)

Tonstall thus insists that Calvinist moral theology should be placed at the centre of the scheme's daily practice. It was a commonplace that the afflicted all too often failed to consider the first cause of their affliction. ${ }^{18}$ The task of suffering Christians was to consider the purposes of providence, to repent from their sins, and thus to sanctify the affliction by using it as an opportunity to turn to God. ${ }^{19}$ Patients should first consult the godly minister when they were sick, rather than waiting until their case was desperate: "When therefore God summons thee, do not as the common course is, send first for the bodily physician, and when thou art past natural care, then for the divine; but contrarily let the divine begin". ${ }^{20}$ Medical practitioners were expected to be "Divines in some measure" by not deluding their patients with false hopes and by encouraging them to make their peace with God and man. ${ }^{21}$ Richard Baxter, who hoped to persuade all physicians that this was their duty, was rather more satisfied than Tonstall on this score: "Blessed be God that very many of the chief Physitians of this Age have by their eminent piety vindicated their profession from the common imputation of Atheism and prophaneness." 22 Regional differences

\footnotetext{
${ }^{18}$ E. Elton, An exposition of the Epistle of Saint Paul to the Colossians, London, 1620, p. 71; J. Hall, Contemplations upon the principal passages in the holy story, London, 1634, pp. 834, 995; S. Crooke, TA DIAPHERONTA: or Divine characters, London, 1658, p. 24; T. Pierson, 'The churches exercise vnder affliction', in Excellent encoragements against afflictions, London, 1647, p. 94.

${ }^{19}$ A. Dent, The plaine mans path-way to heauen, London, 1601, p. 125; R. Sibbes, 'Ivdgements reason', in The saints cordials, London, 1629, pp. 38, 59; L. Bayly, The practice of piety, 3rd ed., London, 1613, pp. 815-16, 818, 832-7; H. Mason, The cvre of cares, London, 1627, pp. 36-9.

${ }^{20} \mathrm{R}$. Sibbes, 'Of the providence of God', in Works, ed. A. B. Grosart, 7 vols, Edinburgh, 1862-4, vol. 5, pp. $43-4$.

${ }^{21}$ M. Day, Comfortable considerations, London, 1621, pp. 1-3; R. Sibbes, A learned commentary ... upon the first chapter of the second Epistle of S. Paul to the Corinthians, London, 1655, p. 136; P. Baynes, Christian letters, London, 1620, sig.G7r; Bayly, op. cit., note 19 above, pp. 909-10.

${ }^{22} \mathrm{R}$. Baxter, The saints everlasting rest, London, 1650, p. 505. For further discussion of this aspect of the relationship between English Calvinism and medicine, see D. N. Harley, 'Spiritual physic, Providence and English medicine, 1560-1640', in Medicine and the Reformation, ed. O. Grell and A. Cunningham, London, Routledge, 1993, pp. 101-17.
} 


\section{David Harley}

in the incidence of godliness, as well as different authorial intentions, may lie behind this disagreement. For a hundred years, however, devout Calvinist ministers and physicians throughout the country attempted to convince the lay public that the two professions were almost exactly homologous, being God's instruments for the cure of soul and body. Healing depended on using the means ordained and trusting in God to grant success.

This belief that concern for their patients' eternal welfare was among the responsibilities of physicians survived the decline of the Calvinist theology of affliction within which it had been embedded for Tonstall and Baxter, but for many Anglicans the duty was confined to deathbeds. An early-eighteenth-century Archdeacon of Durham included among his visitation questions concerning physicians, "Do they diligently exhort their Patients when in danger of Death, to send for the Minister of the Parish, in order to consult him for the Eternal Welfare and Happiness of their Souls?"23 What is distinctive about Tonstall's use of the doctrine of providential affliction is his assertion that this duty of calling the minister should be made a compulsory part of all medical treatment under the scheme, only Catholic paupers being exempt. Tonstall saw the whole operation of the project as guided by providence, which is why he refers to the record of cures as "the Accompt of Gods blessing on our Endeavours towards the Poore" (p.8).

Tonstall's method of promoting the scheme is entirely consonant with his godly purposes. Providence had prompted him to put forward the idea during "my occasional Discourse to a Magistrate of this County, touching the benefits of having an honourable standing maintenance for approved Physitians in this County, and the many sad evills which was dayly contracted by the neglect hereof, and at how easy a charge it may be accomplished" (pp.3-4). In accordance with the Calvinist aim of reformation through the efforts of a godly magistracy, Tonstall first put his proposal to the Quarter Sessions of the county. ${ }^{24}$ Unfortunately, the magistrates thought it lay outside the scope of existing legislation so they refused to recommend the scheme to the parishes: "the Law allowed of no Assessement for reliefe of this nature" (p.5).

Since God had laid this task upon him, Tonstall was obliged to pursue a different strategy. He appealed to the county, bypassing the magistrates with a voluntary subscription scheme. He first decided to mention the matter privately to

the Friends God had given me, and see if they would make contribution, which might be in answer hereunto. And from all that I mentioned it unto, I received such incouragement through their Liberality, that I was induced to move it to the rest of the Country, that all might have notice, and no man be excluded that desired to joyne assistance to this worke of Charity. (p.5.)

He appears to have envisaged a scheme supported by gentry, clergy and parish officers, who would provide the finances on an annual basis and recommend patients

\footnotetext{
${ }^{23}$ Commissioners appointed to inquire into the Rubrics..., second report, London, 1868, p. 684. Similarly, Anglican clergy were expected to remind the sick of the need to settle their temporal affairs: see 'The Order for the Visitation of the Sick' in The book of common prayer.

${ }^{24}$ On the relations of the godly with magistrates, see P. Collinson, The religion of protestants, Oxford University Press, 1982, pp. 141-88.
} 
for treatment, thus anticipating the voluntary hospital movement of the following century.

The details of the medical care to be supplied are equally novel. There is a strong Baconian thread running through Tonstall's proposal, for example in his intention of "Publishing my prescripts, and annexing the observations, what effect they have had over men's infirmities and bodily distempers" (p.2). Tonstall expects the scheme to ensure not only improvements in public health but also

The advance of knowledge, he being ingaged within the limit of the first three Yeares, to write a Booke of the Body of Physicke, which may be supposed the Summe of all his Reading and Study, which being still kept, might further his Successors. And if in his practice, he meet with any perticular secret, he likewise should note that for the same end. (p.4.)

This intention to accumulate clinical data might seem innocuous enough, although somewhat arrogantly phrased, but what was proposed was the revealing of the secrets of both the patient and the practitioner. Tonstall proposes that there should be an arrangement whereby "the Country Physitians, which had most of the practice, were obliged to Register all mens cases as they were presented to them, freely writing the perticulers of their Medicines, then may both Patient and Physitian that comes after him, know better how to proceed, when next occasion is offered." (p.4.) In effect, practitioners were to be asked to lay bare all their professional experience to both patients and rival practitioners.

Many other aspects of the proposal would also be sure to raise the hackles of Tonstall's colleagues, whose support would be necessary for the scheme's success. He shows relatively little regard for the hierarchical division of labour within medicine, seeing mainly a difference of knowledge between the physicians and the three salaried employees of the scheme:

the work is distributed amongst five persons, two Physitians to give advice, the other three to attend and administer it, which they may mutually prosecute without distinction of Surgery, or servant Apothecary; for as our Surgeon with assistant advice, may knowingly and safely give such Physicke as we shall direct; so the other two, having seen the experience of our practice, may be usefull to help (following the direction of the Surgeon and Physitian) the poor people in any bodily infirmity. (p.3.)

This might have been a realistic estimation of the capacity of chemists and apothecaries but it tended to reduce learned physic to mere therapeutics and was not calculated to please Galenists, jealous of their university education in natural philosophy. ${ }^{25}$

This was also the tendency implicit in institutionalizing the rural custom of diagnosing patients on the basis of a urine flask carried by a messenger. The limited utility of uroscopy as a diagnostic technique, and the widespread fraud involved in its

${ }^{25}$ H. J. Cook, 'The new philosophy and medicine in seventeenth-century England', in Reappraisals of the scientific revolution, ed. D. C. Lindberg and R. S. Westman, Cambridge University Press, 1990, pp. 397-436. 


\section{David Harley}

employment, had been widely accepted by the learned since the criticisms of Forestus and Hart. The first maxim of the clergyman Thomas Fuller on "The good Physician" was "He trusteth not the single witnesse of the water if better testimony may be had."26 As Thomas Willis was finding, it was far from easy to wean one's rural clientele from their faith in the casting of urine, so deeply embedded was it in their understanding of medical practice. ${ }^{27}$ Although Tonstall specifies that a form, giving details of the patient and the ailment, should accompany the flask, he makes no provision for a visual inspection by the physician (p.9). If that had been all that was intended, it would indeed have been an inadequate means of arriving at a diagnosis, but Tonstall expected that subscribers in the rural districts would receive his digest of medical knowledge, the record of cases, and the Pharmacopaa Dunelmensis. Thus he was proposing to put sufficient medical knowledge in the hands of the laity to enable them to provide him with clinical descriptions and to follow simple prescriptions. Like the respect shown to the subservient practitioners by Tonstall, this method was reminiscent of the ill-fated endeavours of Théophraste Renaudot in Paris and equally likely to arouse the hostility of learned physicians. ${ }^{28}$ Tonstall might believe, somewhat immodestly, that these books would silence all objections to the scheme (p.8) and put an end to disputes among physicians about the merits of various therapies (p.15), but this was an unrealistic belief. As he discovered when he wrote on Scarborough, trying to devise a pragmatic compromise between Galenism and Helmontianism was likely to please nobody.

Apothecaries too might well be alarmed at his proposal to specify the cost price of prescriptions (p.2), since their income was supposed to derive entirely from the extent to which they could mark up the price. They might also be offended by his suggestion that it would be necessary for the scheme to retain a chemist as well as an apothecary, implying that the Durham apothecaries were competent only to prepare Galenic remedies (p.6). Although his reference to his own experience in chemistry (p.7) is self-effacing by comparison with the claims of many contemporary chemists, non-medical readers might see the claim to divine assistance as boastful. Physicians would undoubtedly see his defiant comments on their covert use of chemical remedies as a threat to orthodox Galenic practice. His announcement that he would be spending the summer at a little local spa (p.11) has the air of self-advertisement and professional control that is characteristic of almost all spa writings. ${ }^{29}$ Tonstall is careful to stress that any payment to the physicians would be entirely at the discretion of the benefactors ( $\mathrm{p} .8$ ) but his colleagues would surely suspect the scheme as promoting the interests of the physicians involved and tending towards the

\footnotetext{
${ }^{26} \mathrm{P}$. Forestus, De incerto, fallaci, vrinarum ivdicio, Leyden, 1589; P. Forestus, The arraignment of vrines, trans. J. Hart, London, 1623; J. Hart, The anatomie of vrines, London, 1625; P. Fuller, The holy state, Cambridge, 1642, p. 53.

${ }^{27}$ Willis's Oxford casebook (1650-52), ed. K. Dewhurst, Oxford, Sandford, 1981, passim. See also the caricatures of old-fashioned physicians in Dutch genre painting of this period.

${ }^{28}$ H. M. Solomon, Public welfare, science and propaganda in seventeenth-century France, Princeton University Press, 1972, pp. 162-200.

${ }^{29}$ D. N. Harley, 'A sword in a madman's hand: professional opposition to popular consumption in the waters literature of southern England and the Midlands, 1570-1870', in The medical history of waters and spas, ed. Roy Porter, Med. Hist. Supplement No. 10, London, WIHM, 1990, pp. 48-55.
} 
engrossment of all practice in their hands, a problem that was to arise with the creation of the provincial hospitals.

For all his defiance of medical tradition in the name of orthodox Calvinism, Tonstall could not escape the public perception of physicians' motives, however unjust this might be when applied to godly doctors. Galenic physicians had acquired a reputation for lusting after lucre which godly practitioners were hard pressed to escape. ${ }^{30}$ Tonstall was well aware that he would be vulnerable to the accusation that his advocacy of the scheme was self-serving, which is why he stresses that God has helped him to overcome the sin of covetousness, "this Gangreen, which corrupts the wellfare of common good" (p.2). Most of his readers, however, would not know how true this was. The elements of self-advertisement in the text, although modest by the standards of the day, might well arouse suspicions in potential subscribers. The scheme would have been more likely to succeed if it had been put forward disinterestedly by Tonstall's friend, the "Christian Magistrate" (p.2).

None of Tonstall's proposals came to fruition and it is unlikely that his pamphlet had any influence on later schemes such as that of the Quaker, John Bellers. ${ }^{31}$ The Durham project must therefore be regarded as little more than an interesting failure, but this was not a foregone conclusion. The scheme was fitted to the mood of improvement that was widespread in England, manifesting itself in Durham in the petitions for the establishment of Durham College. The provision of free comprehensive health care for the poor was not advocated using utopian or millenarian rhetoric. It was presented in terms of religious duty and practical detail. Some of the more radical details, passed over quickly by Tonstall, would not have escaped unnoticed at the time. Not everyone would have cared for the toleration of Catholic paupers, for example, and there were substantial vested interests in favour of the medical status quo, which supposedly ensured a strict hierarchy and division of functions among practitioners, but the proposal probably failed mainly because of the lack of political will. The magistrates, concerned not to appear to be stepping beyond the precise letter of the law in view of the instability of the new regime, refused even to recommend the scheme. With no one vouching for the bona fides of the proponents, the political inertia of the parish officers would surely have been insuperable, given the host of possible objections.

Despite its failure as a practical scheme, Tonstall's proposal is of unusual interest to historians because of the insight it provides into the extent to which godly medical practitioners had internalized the Calvinist view of medical practice as the instrument of God's providence. Physic and surgery were seen as equivalent to the ministry, as God-given means provided for the care of mankind. This view encouraged practitioners to adopt a less arrogant manner, but it endowed medical science and practice with a more dignified status than had been granted by Renaissance humanists.

\footnotetext{
${ }^{30} \mathrm{~S}$. Brant, The shyp of folys of the worlde, trans. A. Barclay, London, 1509, sig.t5r-vlv; H. Latimer, Frvtefull sermons, London, 1575, pt. 1, f.29v; pt.2, ff.101; J. Northbrooke, A treatise wherein dicing, dauncing, vaine playes or enterluds . . . are reproued, London, c. 1577, p. 3; R. Stock, The doctrine and vse of repentance, London, 1610, p. 323; T. Taylor, The principles of christian practice, London, 1634, p. 563.

${ }_{31} \mathrm{~J}$. Bellers, An essay towards the improvement of physick, London, 1714.
} 


\section{The Poore Mans Reliefe}

/1/ Having sent abroad a Paper, signifying, That I desire the Poor as well as the Rich might have the benefit of that Talent which God had given me: which was the scope of that Message to the Parishes of this County binding my selfe by Publique Engagement, to acquit the sincerity of my proposall herein, by registring all the undertakings which providence in this nature should send unto me. I found presently those different effects this generall prescript wrought upon mens humors, many approving it, by attestation of subscription: Others approving the thing, but doubting of the probability of having it effected. For removing of improbabilities (as well as I am able) is the summe of this Relation.

In a publique worke all the Instruments must be answerable to their parts, or otherwise the designe will faile in the doing.

1. The Abillity, Honesty, and Faithfulnesse of the Physition.

2. The liberall and willing Contribution of the Benefactors.

3. The Care and Diligence of the Chyrurgeon and Apothecary.

These are the parts, if any of them fayle, the worke is impayred.

1. To the first, I shall acquaint you with the Objections of mine owne Heart; When I discovered, that Providence did require I should put forward the motion for supply of the Poore, and setling (if it were possible) an honourable Maintenance /2/ for Physitians. The first Objection was, That I could not speak herein, but 'twould savour of Selfe-love, and Covetousnesse, which I had most cause to abhorre of any thing. This was removed, by freely acquainting a Christian Magistrate, how God had dealt with me in cure of this Gangreen, which corrupts the wellfare of common good. The next Objection, was the sad reflection of my distemper and weaknesse of bodily and Spirituall strength, that 'twas not probable I should mannage such publique affaires answerable to my promise and expectation of the County. To this, I thus concluded, That having learned by experience, how much discouragement had wrong'd the free mercy of God, who delights to make his power known by effecting great works with most despicable and improbable Agents, I durst not give way to such thoughts, but to prosecute it so far, as I found his assistance therein: And if it please him to inable me so long, as that I may moddell this undertaking in such a method, that an other may as well execute it as my selfe; when so much is done, then shall my Conscience in discharge of my duty be at quiet. Wherefore I declare, That this proposall is presented upon no other resolution than this, namely, if God please to continue my life and understanding but one Yeare or two, I hope, through his blessing, to acquit mens expectations of the good that will acrew by it; and to let them see, by Publishing my prescripts, and annexing the observations, what effect they have had over mens infirmities and bodily distempers, and rating every such Prescript as equally to their cost of making, as may be: That then I desire to cease and execute it no further, having worke enough at home. But onely to recommend your charitable Contributions to Dr. Edward Wilson, and Mr. William Tonstall, to whom God hath given gifts of minde, and health of body proportionable for so great a worke. 
2. To the second, 'Tis in your hands to looke to it, you may finde some motives following, that will let you see (besides /3/ what your own Consciences will dictate when you are upon your sicke Bedds, and feel the comfort or want of Physitians help) That tis Gods will, You love your Neighbour as your selves.

3. To the third, For the care and diligence of the Chyrurgeon, by nominating the man we shall imploy (his demeanour hath been such already) that I hope tis enough to satisfie you herein, Mr. Thomas Cooper the younger.

For the care of the other, I shall undertake for them, so long as I meddle in this businesse; And then, experience of their accompts will confirme your approbation of them.

These things premised, you may see likelihood enough for a constant settlement of your Charity: and that the work is distributed amongst five persons, two Physitians to give advice, the other three to attend and administer it, which they may mutually prosecute without distinction of Surgery, or servant Apothecary; for as our Surgeon with assistant advice, may knowingly and safely give such Physicke as we shall direct; so the other two, having seen the experience of our practice, may be usefull to help (following the direction of the Surgeon and Physitian) the poor people in any bodily infirmity.

This, I hope, may serve to assure you, That (if plentifull contribution be not wanting) there is probable means enough to doe the Country, both poor and rich, much good. And that you may know how little my hand is in this designe, I shall relate to you, how I neither begun, nor prosecuted it otherwise, then providence directed, my Conscience urging me thereunto.

It was my occasional Discourse to a Magistrate of this County, touching the benefits of having an honourable standing maintenance for approved Physitians in this County, and the many sad evills which was dayly contracted by the neglect hereof, and at how easy a charge it may be accom- /4/ plished. To instance the benefits. First, The succour of the Poore, whose cryes were lowde, that there was none to helpe them, but they must live miserably, or dye desperately, in adventring their bodies into the hands of such as had no promise of Gods assistance and blessing to practice Physicke, being un-called and un-fitted thereunto. And though this evill hath troubled the Common-wealth, as appeares by the Laws made against it, yet could it never be prevented otherwise, then thus, by propounding to them, how they may have advise of Physitians and Physicke for nothing.

Secondly, The good and safety of all: For whereas it is generally believed, after once any hath made use of a Physitian, and God hath blessed the means with Successe; that Party may with more security, rely upon the same Physitians advise, then upon a strangers, who knows not by experience the disposition of the party to Physicke, but onely by probable arguments. Now supposing the Country Physitians, which had most of the practice, were obliged to Register all mens cases as they were presented to them, freely writing the perticulers of their Medicines, then may both Patient and Physitian that comes after him, know better how to proceed, when next occasion is offered.

Thirdly, The advance of Knowledge, he being ingaged within the limit of the first three Yeares, to write a Booke of the Body of Physicke, which may be supposed the Summe of all his Reading and Study, which being still kept, might further his Successors. And if in his practice, he meet with any perticular secret, he likewise should note that for the same end. 
Fourthly, The Glory of God. We say, take away the Cause, and the Effect ceaseth; this is an undeniable Principle, yet ordinarily it is contradicted in the Physitians and Patients practice: For the Cause, Principall, Antecedant, Concomitant, and sine qua non, is Sinne, and that in every Disease, this therefore in right Method should be removed, but it is the 15/ last thought upon. How would God blesse the proceedings of the Phisitian, and Sanctifie the sickenesse of the Patient, if that order were made, That none (if necessity did non prohibit) should expect a Physitians assistance, before the Minister have Visited him, except the sicke party be a Recusant?

To summe up all, Whatsoever evill were desired to be removed, or good done that layd in the power of the Physitian, he being the Countries Servant, might have such Rules prescribed by the ablest of the Benefactors, that he should not transgresse to the prejudice of either soule or body.

And although all this were approved of, yet little hopes appeared, that these wasting times should make up so considerable a summe, as this businesse required: Therefore I presented to the Justices (whom I took to be the Physitians, deputed of God for reliefe of the poor) motives of consideration in behalfe of the indigent people, that they would but consider how many sad events in one Yeare happens, for want of those remedies which were (by Gods Ordinance) as necessary to preserve life in time of infirmity, as Meat and Drink in time of health.

This motion (though approved) yet could not be granted, because the Law allowed of no Assessement for reliefe of this nature. Failing here, I resolved to try the Friends God had given me, and see if they would make contribution, which might be in answer hereunto. And from all that I mentioned it unto, I received such incouragement through their Liberality, that I was induced to move it to the rest of the Country, that all might have notice, and no man might be excluded that desired to joyne assistance to this worke of Charity.

Wherefore I judge it my part to propound these two Cases.

1. I wish (unlesse they resolve to settle a maintenance standing for County Physicians) that I may have the liberty (with /6/ out the ill will or censure of any man) to signifie to those my Relations, who have no jealousie of my proposall, That I may have what contribution they please for the poor Yearely, and I shall faithfully disburse it upon whom they please to recommend to my care, in cases of Physicke and Chirurgery: And they will see Yearely what account I shall be able to give them, wishing from my heart, that all other Physitians would doe the like to their Relations, that so the worke may be better distributed amongst us.

2. If they doe resolve to settle a standing allowance as is expressed, I shall give them my best furtherance and assistance in it, Thus;

First, I consider the charge of Money, That it will be necessary to indent with one Chirurgeon at the least, binding our selves to pay him twenty pounds per Annum, during the time of this Contribution, for his care and pains in cases of Chyrurgery, which we shall recommend to him, giving him our assistance and advice herein; and defraying all his charge that is expended about it.

In like manner it is necessary, That we indent with an Apothecary, allowing him accordingly for making up our prescriptions, and distributing them without payment. 
It is also necessary, That an other be indented with for attending those preparations which are done by the Art of Chimistry; and least people conceive this to be needlesse: I desire to let them know, that it is absolutely necessary and convenient, because none ever practised Physicke, but he found continuall use of such Medicines, though he thought it a point of discretion to cover his practising of them from the knowledge of the Patient, which is generally affrighted with the name of a Minerall, because the unskilfull practice of many, hath occasioned this misprision of Chymistry. If I be not beleeved herein, let any Graduate $/ 7 /$ Artist charge me with a Lye. Besides (to those that know me, I speak) unlesse the Lord had signally instructed me in some thing of this Art, and witnessed his approbation therein, with concurrances of his blessing, I should (since the time I knew my selfe) never have dar'd to harbour one houres studdy in these matters, wherein I had fayled so much in expence of time and money formerly: I will not say more herein, then may be satisfactory to the Contributors, that the hopefull improvement of those scraps, which I have gathered hic \& ubique, I shall bequeath into good hands for their use.

Againe, 'tis necessary that so much be alloted for provisions of Dyet and Lodging, during the Cure of such, whose Malladies require dayly attendance here in Towne.

It is convenient, that there be a Library of Physicke Bookes, and a small Annuall summe for inlarging the same.

These are the Charges, as appurtenances to the maine Disbursements of Medicines and, Maintenance of Physitians.

The Accompt which we have ingaged to Register consists of two parts. First, The Accompt of the Money Received, and how it is Expended: it is done in this Forme.

Contributions of each Parish.

The whole summe of Contribution.

The Disbursements.

For Medicines, as appears by the Apothecaries Bills

To such a sicke person.

Payd for Lodging and Dyet of such

a sicke person for Dayes

18/ Payd for Chyrurgeons, and Messengers, for Charges

of Houses and themselves in their Visits.

Payd for Printing, Writing, and sending

Letters, and for the Collection.

Remaining in our hands for our pains and advice

to be lessened, or augmented, as the Contributors

every Yeare shall think fit. ...

For this is our desire mainly, that Monies be not wanting for necessary charges of Physicke, and attending it. And for our advice, we referr it to the County, when they see what we have done, which will deserve more one Yeare, then another.

The second Part is the Accompt of Gods blessing on our Endeavours towards the Poore.

If this Accompt be without fraud made legible to all mens capacities; then the mouths of false feares and jealousies are stopped: which that they may be, I desire the Information in the behalfe of any poore creature, be in this Forme. 


\section{David Harley}

19/ A. B. Inhabitant of C. about the Age of Yeares; such a Day was in this manner afflicted, contracted as is supposed, by occasion of , or not: who was formerly of sound Health, or otherwise inclineable to such a Distemper. It continued after such manner, till this time This is the Water, we referre him to your Care under God, and we promise for him you shall have an Account what Effect those Meanes shall produce, which you direct.

This I judge requisite, least the Country fashion be observed, in sending their Urine without further Information; supposing we shall know enough thereby, how, safely to Administer Advice in all Cases.

After the Information is Registered, the Advice of the Physitian I promise to Register.

/10/ It is judged, That the Information Signed by A. B doth manifest a putrid Fevor, wherefore let there be Administered after Bleeding, First, A preparitory Potion; A Vomit the next Day; And then a Cordiall sweat, as they are knowne by their Names in the Pharmacopæa Dunelmensis. The Effects whereof, as it hath pleased God to dispose, may be Read in the catalogue of the returnes sent from the poore patients, to be Collected together in one Booke.

So when the Information is Viewed, the Judgement and Advice upon it; the Prescriptions to the Apothecary, how they answer the Advice, and the Returnes what Effect such advice hath produced, I hope I have acquitted the Engagement.

For the Remote Parts, as Darneton Ward, least distance of Place make this Proposall lesse Effectuall in their behalfe; I doe promise to leave a Chest of Medicines, and imploy one thereabout, who shall carefully prosecute the intent of our Designe, with lesse trouble then comming to Durham, except in cases of difficulty.

/11/ This also I wish may be knowne, That two Moneths about Midsummer, being a Season, but in extreame cases, unfit to move the humors in the Body, I shall attend my Duty at the Well on Gaterly Moore, adjacent to this County.

This Water is of the Nature of Sweet Spawes, which partakes of Vitrioll; the Spaw at Knaisborough a little exceeds it in this property, and therefore is more effectuall for Gravell in the Kidnyes: but for Diseases of the Female Sex, proceeding from the Spleene and Matrix; as also for Wormes, and all other Diseases, none excepted (with due care of Physicke taken.) This Water hath the preheminence, (to my judgement and experience) of others in the North Parts; the Reason from hence is, That it partakes of the Tinne and Lead: the former Mettall is approved to be of use in Mens Bodies next to Gold; from the latter, it hath properties which are knowne to Physitians, and therefore is not safe for Women Conceived to meddle with it. I wish this necessary Caveat be not abused to sinne.

/12/ I hope the Country may now be satisfied, That if there be no want on their Parts of Charity, the Poore shall not suffer in losse of Health or Life, so farre as my Care and Endeavour can prevent. And seeing the only ground and bothome of this undertaking (next to the approbation of God) is the good will and opinion of the Contributors, having no feare at all, that they by exceeding their Contribution with Messages of Patients, have purpose to impoverish me in my Actings for the Poore: Wherefore as I hope to be Instrumentally helpfull to them, let no Man forbeare to send to us in their behalfe when there shall be need. These things premised, I desire it may be Published as followeth. 
/13/ These are to signifie, That George Tonstall, and William Tonstall Residing in Durham, have undertaken to supplie any Poore Person, being an Inhabitant of this County, that shall be any way infirme with Advice and Physicke according to their best Skill, in all Cases wherein Physicke or Chirurgery is required (except in the case of common Plague) without any charge to them, from the first of April 1655. And they desire, that such Gentlemen, Free-holders, and others, who thinke fit to Contribute in this Charitable Proposall, towards the Discharge of the Physicke, and necessary Charge hereof, to subscribe their Names, and the Summe they will freely Yearely give, to be returned to us. And that they will Yearely Pay such Summes to the respective Ministers of the severall Parishes, for our Use: the /14/ one moyety on the first of May; and the other moyety on the five and twentieth of December. And they doe Ingage to Register their proceedings, to that end the said Contributers may receive Accompt Yearely how they discharge their Trust herein. Provided such Poore Person Inhabitant as aforesaid, that shall apply themselves unto the said George and William Tonstall, doe procure and send a Note or Certificate from any * three of the said Contributers, that they are of such as are intended within this Charitable Proposall.

/15/ The onely designe next, in prosecution hereof is, to frame a Dispensatory in such a Method, that if any Person can but have true advice what kinde of Remedies is needefull for them to use, then shall it be sufficient direction to mine Apothecary what to give him, without prescribing such and such things in particular. And this, I hope, will be a beneficiall worke, because men prophessing Physick, seldome differ in Judgement concerning what is to be done, and after what manner. The Logicall rules of Art leade men together thus farre: but with what shall our intentions be performed, here lyes the Dispute? For it is naturall, that he that hath made his practice with such Receipts, will not yeeld to alter them upon another commending his. This knot will be loosed, when the Dispensatory is Viewed, with Observations how they tooke effect; Physitians then may judge of them. I wish them so much comfort, as a willing heart, to adjoyne their Receips hereto: And when all is approved on, none need differ in using them.

/16/ An Abstract of the Poore Mans Panacaa, or: Pharmacopaea Dunelmensis.

The Rationall Method of Cure is performed by Indication. And the subject of Indication, is either $\left\{\begin{array}{l}\text { 1. Causa Materialis. } \\ \text { 2. Pars affecta. } \\ \text { 3. Symptomata. }\end{array} \quad\left(\begin{array}{l}\text { Antecedent. } \\ \text { Continent. }\end{array}\right.\right.$

1. The Materiall Cause being præternaturall, hath for its Indication Evacuation,

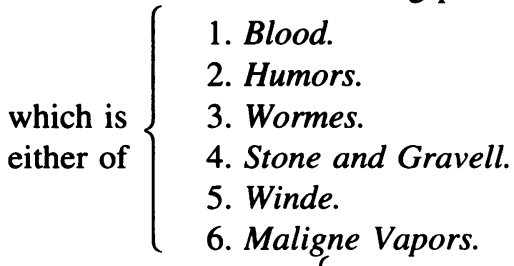
Externall accidents $\left\{\begin{array}{l}\text { Thorns. } \\ \text { Splinters. } \\ \text { Dirt and gravel, \&c. }\end{array}\right.$

\section{*It is intended \\ when \\ conveniency will permit.}

that one

of them be a

Minister. 


\section{David Harley}

Blood hath its Evacuation by Lances, Leeches, \&c.

Humors are divided
ordinarily into $\left\{\begin{array}{l}\text { Choller. } \\ \text { Phlegme. } \\ \text { Melancholy. } \\ \text { Water. }\end{array}\right.$

These have their proper Evacuatories

Evacuatories $\left\{\begin{array}{l}\text { in Generall are }\left\{\begin{array}{l}\text { /17/ } \\ \text { Vomits. } \\ \text { Purges. } \\ \text { Salivation. } \\ \text { Sweats. } \\ \text { Diureticks. } \\ \text { Blistering. } \\ \text { Fomentations. }\end{array} \quad \mathrm{X} \text { handwritten] }\right.\end{array}\right.$

[by hand]
which are
either $\left\{\begin{array}{l}\text { Internall }\left\{\begin{array}{l}\text { Drinke. } \\ \text { Cordial Electuries. } \\ \text { and Powders. }\end{array}\right. \\ \text { in Particular, } \\ \text { Externall } \\ \text { Fuming. }\end{array}\left\{\begin{array}{l}\text { Errhina. } \\ \text { Apophlegmatismi. } \\ \text { Tussilagogs, \&c. }\end{array}\right.\right.$

Evacuatories by Stoole $\left\{\begin{array}{l}\text { Pills. } \\ \text { Electuaries. } \\ \text { Potions. } \\ \text { Powders. }\end{array}\right.$

As Reason sees cause to vary.

2. The part affected: This hath for its Indication, Corroboration, which is performed by opposition of helps Homogenial to the temperament, and Humidum radicale. This Humidum radicale, consists in the influentiall heate of the Heart (which communicates its life $/ 18 /$ and vigour to the whole Body) and the innate heate of every Part or Member.

These helps are $\left\{\begin{array}{l}\text { Aliments. } \\ \text { Medicaments. }\end{array}\right.$

Medicaments are such as we call, Cephalicks, Pectoralls, Cordialls, Stomachicks, Spleneticks, Hepaticks, Renall, and Matricall; these are peculiar to the noble parts of the Body, which respect the innate heate of each particular part, with a sweet spirit agreeable to the Vitalls: The variation of this Indication is onely in respect of the temperament in

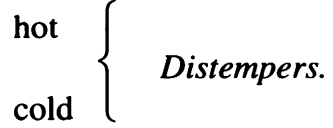

3. Symptoms. These are such Effects as follow the Disease, and have for their Indication their contraries.

The common Symptome, is paine; its contrary is Anodine. 
The other Symptoms are divided,

1. Spirits, as $\quad\left\{\begin{array}{l}\text { Spirits. } \\ \text { Blood and Humors. } \\ \text { Want of Sense. } \\ \text { Want of Motion. } \\ \text { Watchfulnesse. } \\ \text { Drowsinesse. }\end{array}\right.$

2. Blood and Humors.

These are divided in
respect of their $\left\{\begin{array}{l}\text { Qualities } \\ \text { Motion. }\end{array}\left\{\begin{array}{l}\text { First. } \\ \text { Second. }\end{array}\right.\right.$

1. First Qualities are
2. Second Qualities are $\left\{\begin{array}{l}\text { Heat. } \\ \text { Cold. } \\ \text { Moysture. } \\ \text { Drynesse. } \\ \text { Thinnesse. } \\ \text { Clamminesse. } \\ \text { Grossenesse. } \\ \text { the Head. } \\ \text { the Stomacke. } \\ \text { the Belly. } \\ \text { the Liver. } \\ \text { the Kidneyes. } \\ \text { the Matrix. }\end{array}\right.$

Thus the materiall Cause, which is the maine opponent, is discovered; the part affected strengthened, and the Symptoms removed; which comprehend the whole Method of Cure belonging to the Physitian.

120/ Now followeth Chirurgery, which is a Method performed by manuall operation upon the Body. The parts whereof

are either $\left\{\begin{array}{l}\text { Similare. } \\ \text { 1. Similare are } \\ \text { 2. Organicall. } \\ \left\{\begin{array}{l}\text { Bones. } \\ \text { Nerves. } \\ \text { Veines and Arteries. } \\ \text { Membrans. } \\ \text { Flesh. } \\ \text { Head. } \\ \text { Palate. } \\ \text { Ears. } \\ \text { Eyes. } \\ \text { Nose, \&c. }\end{array}\right.\end{array}\right.$ 


\section{David Harley}

Infirmities belonging to $\left\{\begin{array}{l}\text { Tumors. } \\ \text { Ulcers. } \\ \text { Wounds. } \\ \text { Imposthumes. } \\ \text { Contusions. } \\ \text { Gangrenes. }\end{array}\right.$

$121 /$

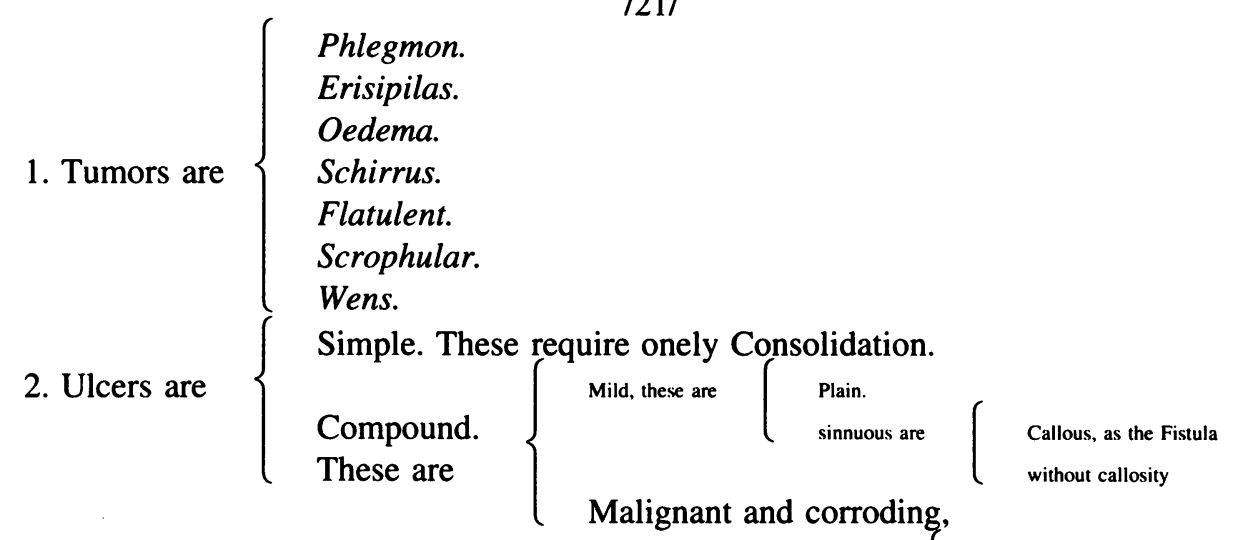

$$
\text { these are }\left\{\begin{array}{l}
\text { Herpes. } \\
\text { Phagedaina. } \\
\text { Noema. } \\
\text { Cancer. } \\
\text { Leprosie. }
\end{array}\right.
$$

3. $\int$ Wounds.

4. $\{$ Imposthums.

5. Contusions.

6. Gangrens, vary according to the division of the Parts.

The Remedies answerable to all Indications in Physicke and Chyrurgery, shall (God /22/ willing) be fitly Composed and Annexed to every branch of Indication, expressed in this Abstract. Therefore when the Pharmacopaa Dunelmensis is Compiled, you may see our businesse is little more, then to give advice.

This Commodity also will arise, That if the Contribution will amount to no more then will finde the Poore with all Medicines necessary for Physicke or Chyrurgery; then may they have Advice gratis from any Artist, having such Remedies for their use in all Cases, as shall be Published.

\section{FINIS}

